\title{
EKSISTENSI CSR SEBAGAI AGEN PEMBANGUNAN DI PROVINSI RIAU
}

\author{
Herman, S.Sos., M.Si \& Rosmita, S.Sos., M.Si
}

\begin{abstract}
Development is a process of change made by the government to the community. In this paper the development is carried out through CSR activities in Riau Province through the elements of stakeholders consisting of the Company itself, the community as a platform for CSR activities, and the Government as the regulatory and supervisory function. This paper discusses how CSR as an agent for poverty alleviation can be done through community empowerment activities which include development, improving the quality of human resources, education, health, economy and even the environment. The role of stakeholders in this case is the benefits received by the company in implementing CSR activities, the benefits of implementing CSR for the community, and the benefits of implementing CSR for the government. While the CSR controversy can be seen through the aspect of regulation that focuses on sanctions against companies that do not implement CSR and the amount of costs that must be incurred by the company in its implementation. The oversight function in this case is the Regional Regulation in Riau Province where the supervision has not been going well. Whereas the determination of Ring consisting of Ring 1, Ring 2 and Ring 3 also has not proceeded in accordance with what should have been where many villages were supposed to get the Ring 1 category but were not categorized. So this thing needs an action so that in the future it can run as it should.
\end{abstract}

Keywords: CSR, Implementation, Development, Stakeholeders

\section{PENDAHULUAN}

Pembangunan merupakan suatu proses perubahan disegala bidang yang sasaran dan tujuannya adalah untuk kesejahteraan masyarakat sebagai mana yang dicita-citakan oleh bangsa Indonesia. Pembangunan tersebut dilakukan dalam berbagai sektor, baik dari segi pembangunan ekonomi, fisik, sosial, budaya, industri, dan lain sebagainya (Herman, 2017:1). Menurut Kartasasmita (1996:6) Pembangunan pada hakikatnya adalah dari dan untuk seluruh rakyat. Oleh sebab itu, kebijakan didalam pembangunan harus berdasarkan kehendak rakyat, kebutuhan lingkungan, adil dan 
makmur serta perencaanaan yang matang.

Salah satu bentuk konkrit dari kebijakan untuk pelaksanaan pembangunan adalah diterbitkannya Undang-undang Nomor 40 Tahun 2007 Tentang Perseroan Terbatas. Pada Undang-undang tersebut dalam salah satu pembahasannya adalah mengenai corporate social responsibility (CSR) atau lebih dikenal dengan nama tanggunjawab sosial perusahaan, pada Undangundang ini yang membahas tentang CSR yaitu: Pada BAB V Tanggung Jawab Sosial Dan Lingkungan, Pasal 74 Ayat 1, 2, 3 dan 4, yang berbunyi:

1. Perseroan yang menjalankan kegiatan usahanya di bidang dan/atau berkaitan dengan sumber daya alam wajib melaksanakan Tanggung Jawab Sosial dan Lingkungan.

2. Tanggung Jawab Sosial dan Lingkungan sebagaimana dimaksud pada ayat (1) merupakan kewajiban Perseroan yang dianggarkan dan diperhitungkan sebagai biaya Perseroan yang pelaksanaannya dilakukan dengan memperhatikan kepatutan dan kewajaran.

3. Perseroan yang tidak melaksanakan kewajiban sebagaimana dimaksud pada ayat (1) dikenai sanksi sesuai dengan ketentuan peraturan perundangundangan.

4. Ketentuan lebih lanjut mengenai Tanggung Jawab Sosial dan Lingkungan diatur dengan Peraturan Pemerintah.

Di Provinsi Riau pelaksanaan program CSR juga telah dilakukan oleh perusahaan-perusaan baik skop Nasional mupun Internasional, baik itu BUMN maupun perusahaanperusahaan Swasta. Pelaksanaan program CSR dilakukan karena ada kebijakan regulasi, adanya orangorang yang terlibat dalam pelaksaannya, serta adanya lembagalembaga yang melaksanakan kegiatan atau program tersebut. Oleh sebab itu, pelaksanaan CSR tidak terlepas dari peranan stakeholders dalam implementasinya (Herman, 2018:265). Namun tidak bisa 
dipungkiri bahwa pelaksanaan CSR

di Provinsi Riau dirasa belum merata yang dirasakan oleh masyarakat, baik masyarakat yang berada disekitar perusahaan maupun masyarakat secara umum yang terkena dampak dari berjalannya perusahaan. Oleh sebab itu maka penulis tertarik untuk mengangkat tema ini dengan rumusan masalah: Bagaimanakah

Eksistensi CSR Sebagai Agen Pembangunan di Provinsi Riau.

\section{KERANGKA KONSEPTUAL} 2.1 Teori CSR

Menurut Handjaja (2013:1) Corporate Social Responsibility atau yang lebih dikenal dengan CSR merupakan sebuah komitmen dari suatu perusahaan untuk memberikan kontribusi yang lebih pada masyarakat, baik melalui tindakan sosial maupun tanggung jawab lingkungan. Susanto (2007:44) menjelaskan bahwa tangung jawab sosial perusahaan atau CSR adalah merupakan suatu keadaan dimana sebuah perusahaan yang menunjukkan tanggung jawab sosialnya akan memberikan perhatian kepada peningkatan kualitas perusahaan (profit); masyarakat, khususnya komunitas sekitar (people); serta lingkunan hidup (planet). Pendapat diatas menjelaskan bahwa CSR merupakan tanggung jawab perusahaan terhadap masyarakat yang ada disekitar perusahaan yang mana tujuannya adalah membantu tugas dari pemerintah baik dibidang pembangunan maupun bidang sosial lainnya dan fokus terhadap kehidupan dan keberlanjutan orang banyak, lingkungan dan perusahaan. Pendapat lain tentang pengertian CSR yaitu menurut Menurut The World Business Council for Sustainable Development (dalam Nurbaety, 2015:141) CSR merupakan bentuk komitmen perusahaan untuk bertindak secara etis terhadap pemangku kepentingan secara langsung maupun tidak langsung dengan meningkatkan kualitas hidup dan kesejahteraan dengan mempertimbangkan aspek sosial, ekonomi, dan lingkungan dari aktivitas perusahaan. Selanjutnya menurut Sankat, Clement K (dalam Erni, 2015:3). Corporate social 
responsibility merupakan komitmen usaha untuk bertindak secara etis, beroperasi secara legal dan berkontribusi untuk peningkatan ekonomi bersamaan dengan peningkatan kualitas hidup dari karyawan dan keluarganya, komuniti lokal dan masyarakal secara lebih luas. Oleh sebab itu, dengan adanya perusahaan disuatu daerah atau komunitas tertentu hendaknya bertanggung jawab secara penuh terhadap masyarakat setempat yang ada disekitar lingkungan perusahaan karena hal ini telah diwajibkan dalam Regulasi yaitu Undang-undang Nomor 40 Tahun 2017 Tentang Perseroan terbatas serta banyak regulasi lain yang mengatur tentang CSR ini.

\section{Kegiatan CSR perusahaan} idealnya bermanfaat bagi masyarakat luas, adapun manfaat CSR Menurut Wahyuningrum (2015:111) yaitu manfaat CSR Perusahaan yang telah meyakini CSR sebagai suatu kewajiban bagi perusahaan, maka dengan sendirinya perusahaan telah melaksanakan investasi sosial. Jadi pada dasarnya kegiatan CSR merupakan investasi sosial dimana dengan melaksanakan kegiatan CSR maka perusahaan dapat melaksanakan keberlanjutan roda perusahaannya menjadi suatu kebutuhan dan bukannya kewajiban.

\subsection{Stakeholders}

Stakeholders merupakan pemangku kepentingan didalam suatu organisasi dalam rangka untuk menentukan arah kebijakan organisasi kearah yang lebih baik. Menurut Azheri stakehoders adalah keterkaitan yang didasari oleh kepentingan tertentu. Dari berbagai definisi diatas dapat penulis ambil kesimpulan bahwa stakeholders merupakan kesatuan individu maupun kelompok yang dapat mempengaruhi keputusan didalam organisasi dalam pelaksaaannya baik organisasi publik maupun organisasi bisnis. stakeholders pada dasarnya terdiri dari tiga komponen yaitu pemerintah, swastan dan masyarakat dimana stakeholders ini saling bersinergi dalam rangka melaksanakan pembangunan.

Seperti yang diketahui stakeholders pada dasarnya terdiri 
dari tiga komponen, yaitu masyarakat, pemerintah dan swasta. Menurut Waddock dan Graves (dalam Mardikanto, 2015:172), stakeholders terdiri dari dua, yaitu stakeholders primer dan stakeholders skunder. Stakeholders primer terdiri dari pemilik perusahaan, karyawan perusahaan itu sendiri, pelanggan, dan pemasok. Sedangkan pemangku kepentingan sekunder terdiri dari organisasi nonpemerintah (LSM), aktivis dan akademisi, masyarakat, dan pemerintah. Selanjutnya menurut Maryono et al. (dalam Handayani, 2017:2) stakeholders dibagi menjadi 3 kelompok, antara lain:

1. Stakeholders primer. Stakeholders primer merupakan stakeholders yang terkena dampak secara langsung baik dampak positif maupun dampak negatif dari suatu rencana serta mempunyai kaitan kepentingan langsung dengan kegiatan tersebut.

2. Stakeholders kunci. Stakeholders kunci adalah mereka yang memiliki kewenangan legal dalam hal pengambilan keputusan.

3. Stakeholders sekunder atau pendukung. Stakeholders pendukung merupakan stakeholders yang tidak memiliki kepentingan langsung terhadap suatu rencana tetapi memiliki kepedulian yang besar terhadap proses pengembangan.

Stakeholder pendukung meliputi para investor atau pihak swasta, LSM, dan peneliti.

Menurut Freeman (dalam Mardikanto, 2014:171) mengartikan stakeholders sebagai kelompok atau individu yang dapat mempengaruhi atau dipengarui oleh pencapaian tujuan organisasi. Menurut Wheelen dan Hunger (dalam Wibisono, 2007:90) Stakeholders adalah pihakpihak atau kelompok-kelompok yang berkepentingan, baik langsung maupun tidak langsung terhadap eksistensi atau aktivitas perusahaan dan karenanya kelompok tersebut mempengaruhi dan dipengaruhi oleh perusahaan. Selanjutnya Sidharta 
(dalam Gantino, 2016:22) menjelaskan bahwa dalam teori stakeholders pelaksanaan CSR tidak hanya dihadapkan kepada pemilik atau kepada pemegang sahamnya saja, tetapi juga terhadap para stakeholders yang terkait dan terkena dampak dari keberadaan perusahaan. Menurut Bryson (dalam Astuti, 2019:248) stakeholders merupakan pihak-pihak yang terkait di masyarakat baik kelompok masyarakat, maupun individu yang memiliki suatu kepentingan terhadap sebuah organisasi, perusahaan, atau permasalahan yang sedang diangkat. Adapun manfaat dari pendekatan stakeholders ini menurut Mardikanto (2014:173) adalah agar kemampuan manjemen pemangku kepentingan akan terkait secara positif dengan pengembangan strategi lingkungan yang proaktif oleh UKM. Peran stakeholders dalam program pembangunan menurut Nugroho (Dalam Astuti, 2019:250) diklasifikasikan berdasarkan peranannya, antara lain:

1. Policy creator, yaitu stakeholders yang berperan sebagai pengambil keputusan dan penentu suatu kebijakan.

2. Koordinator, yaitu stakeholders yang berperan mengkoordinasikan stakeholders lain yang terlibat.

3. Fasilitator, yaitu stakeholders sebagai fasilitator yang berperan memfasilitasi dan mencukupi apa yang dibutuhkan kelompok sasaran.

4. Implementor, yaitu stakeholders pelaksana kebijakan yang di dalamnya termasuk kelompok sasaran.

5. Akselerator, yaitu stakeholders yang berperan mempercepat dan memberikan kontribusi agar suatu program dapat berjalan sesuai sasaran atau bahkan lebih cepat waktu pencapaiannya.

\subsection{Pembangunan}

Pembangunan

menurut

Tjokrowinoto (dalam Purnamasari, 
2008:18) adalah pergeseran dari suatu kondisi nasional yang satu menuju kondisi nasional yang lain, yang dipandang lebih baik dan lebih berharga. Disamping itu pembangunan juga merupakan proses multi dimensional yang menyangkut perubahan-perubahan yang penting dalam suatu struktur, sistem sosial ekonomi, sikap masyarakat dan lembaga lembaga nasional dan akselerasi pertumbuhan ekonomi, pengangguran, kesenjangan dan pemberantasan kemiskinan absolut. Pembangunan menurut Siagian (dalam Suryono, 2010:2) sebagai suatu arah atau rangkaian usaha pertumbuhan dan perubahan yang berencana dan dilakukan suatu bangsa, negera dan pemerintahan secara sadar menuju modernitas dalam rangka pembinaan bangsa (nation building).

Selanjutnya menurut Bryan and White (dalam Suryono, 2010:2) menyebutkan bahwa pembangunan adalah upaya meningkatkan kemampuan manusia untuk mempengaruhi masa depannya dengan memiliki lima implikasi utama yaitu: (1) membangun berarti membangkitkan kemampuan manusia secara optimal, baik individu maupun kelomppok (capacity), (2) pembangunan berarti mendorong tumbuhnya kebersamaan, kemerataan nilai dan kesejahteraan (equity), (3) pembangunan berarti menaruh kepercayaan kepada masyarakat untuk membangun dirinya sendiri sesuai dengan kemampuannya (empowerment). (4) pembangunan berarti membangkitkan kemampuan untuk membangun secara mandiri (sustainability). (5) membangun berarti mengurangi ketergantungan negara atau satu kepada negara lain, menciptakan hubungan yang saling menguntungkan dan menghormati (independence).

Pelaksanaan pembangunan hendaknya bukan hanya berjalan ditempat saja, namun meski berkelanjutan. Menurut Lawalata (2013:116) ) menjelaskan bahwa pembangunan berkelanjutan merupakan upaya untuk memenuhi kebutuhan dasar semua dan berkembang menjadi kesempatan untuk memuaskan aspirasi manusia untuk kehidupan yang lebih baik. 
Dapat digambarkan bahwa pilar yang mendukung sifat berkelanjutan adalah aspek sosial (kebutuhan standar manusia), aspek lingkungan (ekologi atau bumi), dan aspek ekonomi (uang atau keuntungan).

\section{PEMBAHASAN}

Dalam pembahasan ini penulis membagi tema bahasan menjadi beberapa bagian, yaitu CSR sebagai penggerak roda penanggulangan kemiskinan, Manfaat Peran stakeholders Dalam Implementasi CSR (manfaat untuk perusahaan, masyarakat dan pemerintah), dan kontroversi CSR yang terdiri dari kritik terhadap regulasi, fungsi pengawasan dari pemerintah serta penentuan Ring.

\subsection{CSR Sebagai Penggerak Roda}

\section{Penanggulangan Kemiskinan}

Masalah kemiskinan disetiap negara memang sulit untuk diatasi, baik negara maju itu sendiri, negara berkembang bahkan negara miskin sekalipun. Tetapi bukan tidak mungkin masalah kemiskinan bisa ditekan angkanya, salah satu cara yang dilakukan adalah dengan membangun masyarakat yang mampu bersaing di dunia kerja yang sudah pasti masalah ini adalah tanggungjawab dari pemerintah dan swasta. Menempatkan swasta menjadi rekan kerja atau patner dalam menanggulangi kemiskinan adalah hal yang sah-sah saja karena adanya kerjasama antara pemerintah dan swasta dalam hal untuk penanggulangan kemiskinan melalui kegiatan CSR merupakan suatu kewajiban, karena tanpa adanya kerjasama maka kegiatan CSR tidak mungkin bisa berjalan dengan semestinya.

Salah satu fungsi CSR adalah melakukan pemberdayaan terhadap masyarakat untuk meningkatkan kualitas hidupnya. Namun pada kenyataannya bahwa implementasi pelaksanaan program CSR tersebut belum lah tepat sasaran secara keseluruhan, masih ditemui pelaksanaan program CSR dilakukan tidak secara berkelanjutan (continue) sesuai dengan harapan semua pihak, masih dijumpai dilapangan terjadinya kecemburuan sosial dalam pelaksanaannya. Selain itu, pemberdayaan masyarakat disekitar 
lingkungan perusahaan tersebut berdiri masih menjadi sorotan hal layak. Dalam hal ini pada saat perekrutan sumber daya manusia (resources) misalnya, masih terjadinya gesekan disana sini. Hal ini dapat dilihat dimana masyarakat pada umumnya merasa pegawai yang diterima untuk bekerja diperusahaan tersebut kebanyakan bukan orang tempatan disekitaran perusahaan berdiri.

Dari hal tersebut diatas dapat kita menilai apakah pelaksanaan program CSR hanya sebagai pelengkap saja demi keberlanjutan hidup perusahaan, ataukah CSR hanya sebagai kewajiban saja, ataukah CSR merupakan kebutuhan dari perusahaan tersebut secara utuh. Modelnya yang sifatnya hanya per proyek, habis proyek ya selesai sudah.

\subsection{Manfaat Peran Stakeholders}

\section{Dalam Implementasi CSR}

Agar pelaksanaan program CSR dapat berjalan dengan baik, hendaknya para Stakeholders dapat berperan secara maksimal. Kartini (2013:8) mengatakan bahwa
Stakeholders merupakan sebagai setiap kelompok atau dindividu yang dapat mempengaruhi atau dipengaruhi oleh pencapaian tujuan perusahaan. Namun pada kenyataanya sebahagian dari Stakeholders baik primer maupun skunder berjalan tidak sesuai dengan yang seharusnya, misalnya pihak corporate/perusahaan enggan melaksanakan kegiatan CSR yang mana kegiatan tersebut hanya merugikan perusahaan semata karena biaya yang dikeluarkan. Peran pemerintah dalam hal ini kurang maksimal baik dari masalah regulasi yang meringankan perusahaan maupun kurangnya fungsi pengawasan yang dilakukan, serta masyarakat yang tidak menikmati CSR secara maksimal dikarenakan faktor-faktor diatas.

\subsubsection{Manfaat Peran Perusahaan}

Pelaksanaan program CSR tanpa disadari sebenaranya sangat bermanfaat sekali bagi perusahaan dalam rangka untuk kelangsungan kehidupan organisasi kedepannya. Menurut Mardikanto (2015:129) 
Beberapa alasan mengapa CSR perlu dilaksanakan yaitu:

1. Merupakan hal yang etis dilakukan

2. Meningkatkan citra perusahaan

3. Menghindari peraturan yang berlebihan

4. Kegiatan ini dapat mengunguntungkan

5. Lingkungan sosial yang lebih baik

6. Menarik minat investor

7. Dapat meningkatkan motivasi karwawan.

Hal diatas menerangkan bahwa sangat banyak manfaat perusahaan jika melaksanakan kegiatan CSR, dengan demikian maka karyawan perusahaan akan bekerja secara maksimal karena tidak ada ganggunan dan gesekan dari pemerintah dan masyarakat setempat karena rasa aman dalam bekerja salah satu keinginan dari karyawan sebuah perusahaan.

\subsubsection{Manfaat Peran Masyarakat}

Bagiamanapun pelaksanaan CSR tidak akan berjalan dengan baik tanpa adanya masyarakat yang menjadi sasaran perusahaan, baik masyarakat secara khusus maupun masyarakat secara umum.
Seperti yang disampaikan oleh Clark (dalam Mardikantor, 2015:134) manfat CSR bagi masyarakat yaitu:

1. Peluang kesempatan pengalaman pelatihan.

2. Pendanaan investasi komunitas dan pengembangan infrastruktur.

3. Keahlian komersial (keahlian berlaba).

4. Kompetensi teknis (keahlian melalui pelatihan).

\subsubsection{Manfaat CSR Bagi}

\section{Pemerintah}

Pelaksanaan CSR juga bermanfaat bagi pemerintah, menurut Mardikanto (2015:135), salah satu manfaatnya adalah dengan keberadaan perusahaan maka akan dapat mengurangi beban pemerintah. Kehadiran CSR bermanfaat bagi pemerintah yaitu:

1. Dukungan pembiayaan (membantu pembangungunan, pengentasan kemiskinan dll);

2. Dukungan sarana dan prasarana (ekonomi, kesehatan, pendidikan, pelatihan, tempat ibadah, sarana olahraga, kesenian dll);

3. Dukungan keahlian (melalui keterlibatan personil perusahaan pada kegiatan penembangan kapasitas masyarakat); 
4. Keterlibatan penggiat LSM dalam kegiatan CSR.

3.3.1 Kritik Terhadap Undang-

Kegiatan CSR ini sangat membantu pemerintah. Bagaimana tidak, selain membayar pajak perusahaan juga mesti melakukan kegiatan CSR yang keduanya adalah hukumnya wajib. Di Indonesia manfaat pajak tidak bisa dirasakan secara langsung oleh masyarakat kelas bawah, orang miskin dan komunitas terpecil baik adat, desa dan lain sebagainya. Oleh sebab itu hendaknya pemerintah jangan lepas tangan terhadap permasalahan lingkungan dan sosial disekitar perusahaan.

\subsection{Kontroversi CSR}

Tidak bisa dipungkiri bahwa pelaksanaan CSR ini walaupun baik maksudnya namun masih saja buruk tanggapannya bagi berbagai kalangan, hal ini tidak terlepas dari hal-hal yang terjadi pada saat implementasinya. Ada beberapa hal yang penulis kritisi dalam pelaksanaan CSR ini yang penulis sadur dari berbagai tulisan baik dari buku referensi, hasil penelitian dan pengamatan penulis sendiri.

\section{Undang Nomor 40 Tahun 2007}

Banyak Regulasi atau
peraturan yang mengatur tentang
pelaksanaan CSR ini, diantaranya
adalah Undang-Undang Nomor 40
Tahun 2007 Tentang Perseroan
Terbatas. Dari Undang-Undang
diatas dapat dilihat pada ayat 1 yaitu
Perseroan yang menjalankan kegiatan usahanya di bidang dan/atau berkaitan dengan sumber daya alam wajib melaksanakan Tanggung Jawab Sosial dan Lingkungan, artinya setiap perusahaan wajib melaksanakan kegitan CSR hanyalah berkaitan dengan sumber daya alam saja, tetapi perusahaan yang bergerak dibidang lain seperti perusahaan jasa, perbankan dan perusahaan lainnya yang bukan bergerak dibidang sumber daya alam tidak wajib melaksanakna CSR. Selanjutnya pada ayat 3 yaitu jika perusahaan tidak menjalankan kegiatan CSR dikenai sanksi sesuai dengan ketentuan peraturan perundangundangan. Pertanyaanya undangundang mana yang mengatur tentang sanksi jika perusahaan tidak 
melakukan kegiatan CSR?

Sedangkan Undang-Undang tentang CSR saja tidak mandiri atau masih menupang di Undang-Undang Nomor 40 Tahun 2007 yang juga tidak ada membahas tentang sanksi.

\subsubsection{Fungsi Pengawasan Dari Pemerintah}

Dalam pelaksanaan CSR fungsi pengawasan melekat pada pemerintah, artinya apa saja yang dilakukan oleh perusahaan terhadap masyarakat sebagai objek sasaran program CSR mesti dipantau langsung oleh pemerintah. Didalam Undang-Undang yang membahas tentang CSR, tidak ada pelaksanaan pengawasan yang dibahas, bahkan di Peraturan Pemerintah pun tidak ditemukan. Namun didalam Peraturan Daerah di masing-masing Daerah ada sub pembahasan mengenai Pengawasan ini, misalnya pada Peraturan Daerah Provinsi Riau Nomor 6 Tahun 2012 Tentang Tanggung Jawab Sosal Perusahaan Di Provinsi Riau. Pada Pasal 29 dan 30 dibahasa mengenai pengawasan tersebut.
Mengingat fungsi pengawasan yang dilakukan oleh pemerintah Provinsi Riau mengenai tanggung jawab sosial perusahaan ini dilakukan oleh DPRD yang membidangi komisi tertentu bersama Forum TJSP yang sebagai mana termuat dalam pasal 26 ayat (2) terdiri dari Gubernur pada tingkat provinsi, Bupati/walikota pada tingkat Kabupaten/Kota, beranggotakan Unsur SKPD terkait, Asosiasi Pengusaha, Perguruan Tinggi, Lembaga Adat Melayu Riau, dan forum sejenisnya. Tetapi pengawasan yang dilakukan oleh forum ini meski diperlukan hal yang lebih mendalam lagi agar fungsi pengasawasan tersebut benar-benar berjalan dengan baik sesuai dengan kaidah pelaksanaannya.

\subsubsection{Penentuan "Ring"}

Salah satu permasalahan dalam penerapan CSR adalah tentang "Ring" yang meruapakan titik dampak dari penerima CSR dari perusahaan ke masyarakat. Ring merupakan wilayah yang berkemungkinan mendapat prioritas utama dalam implementasi kegiatan 
CSR yang mempunyai tingkatan, menurut Soemanto (2007:45) penentuan Ring tersebut dapat dirincikan sebagai berikut:

1. Ring 1, adalah daerah yang menerima dampak paling besar,

2. Ring 2, adalah daerah yang menerima dampak menengah,

3. Ring 3, wilayah yang menerima dampak paling kecil atau sama sekali tidak ada dampak.

Dari hal diatas dapat dipertanyakan bahwa Dasar penentuan Ring tersebut apa kategorinya? bagaimana masalah Ring ini diterapkan di Kabupaten Pelawanan yang merupakan salah satu Kabupaten yang ada di Prvinsi Riau. Nah, banyak Desa di Kabupaten Pelalawan oleh perusahaan terkategorikan Ring 3, padahal perlu diketahui banyak tanah ulayat desa yang dipakai oleh perusahaan misalnya desa Rangsang, Desa Tolam, Desa Sungai Ara, Desa Sering dan lain-lain. Bayangkan saja dengan adanya ekspansi perusahaan bubur kertas di Desa tersebut menyebabkan merka tidak pernah lagi melihat kayu-kayu berukuran besar, madu sialang yang merupakan

komuditi kebanggaan dan banyak lagi efek atau akibat dari ekspansi perusahaan, belum lagi dampakdampak lain yang ditimbulkan.

\section{KESIMPULAN DAN SARAN}

Berikut akan penulis sampaikan beberapa kesimpulan dan saran yang penulis ambil dari intisari penulisan makalah ini:

\subsection{Kesimpulan}

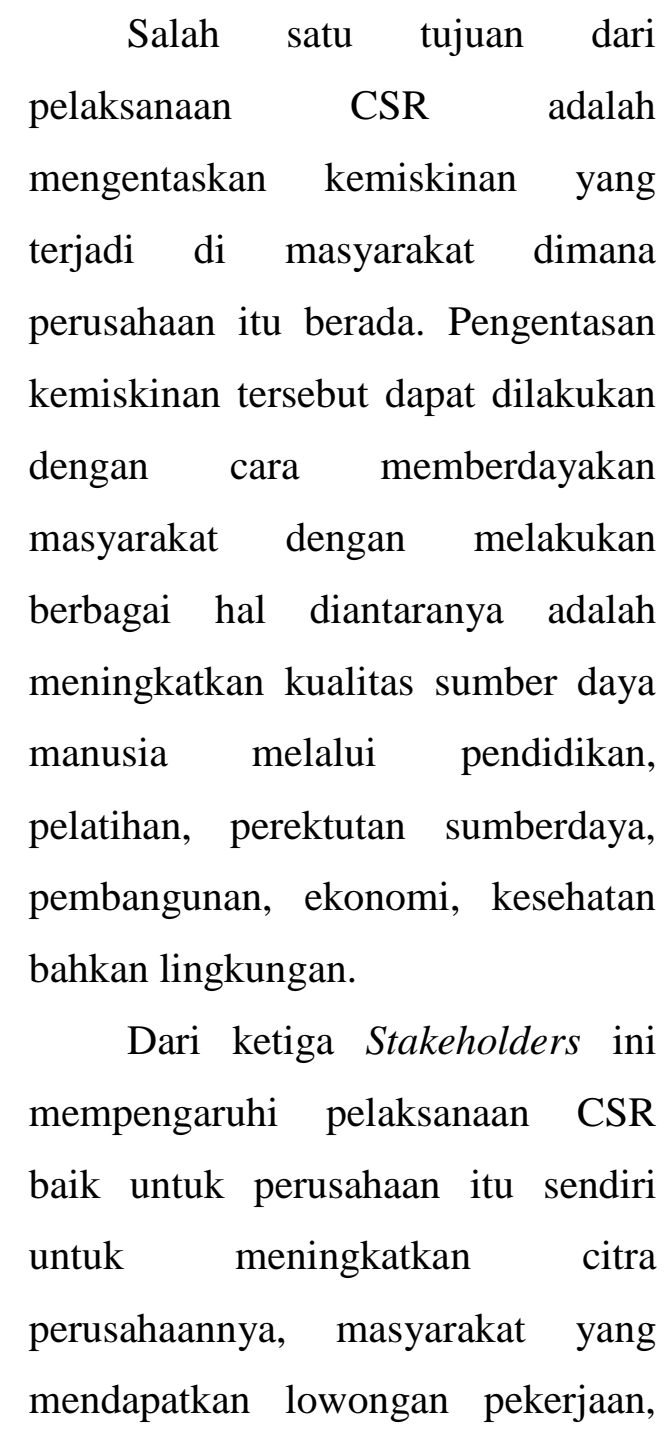


pelatihan dan pendidikan, mupun pemerintah yang terbantu karena adanya pelaksanaan CSR. Namun masih ada catatan penting bahwa peran Stakeholders ini masih berjalan belum sesuai dengan harapan.

Kontroversi CSR di Provinsi Riau yang terdiri dari: Pertama, kritik terhadap regulasi CSR dimana untuk Undang-undang Nomor 40 Tahun 2007 tidak jelas dalam penerapan sanksi dan pendanaan untuk CSR. Kedua, mengenai pengawasan yang dilakukan melalui Peraturan Daerah Provinsi Riau Nomor 6 Tahun 2012 Tentang Tanggungjawab Sosial Perusahaan di Provinsi Riau dimana fungsi pengasawasan tersebut tidak berjalan dengan sesuai koridornya.

\subsection{Saran}

Dengan adanya perusahaan di Provinsi riau yang scopnya Nasional dan Internasional, hendaknya mampu untuk menjalankan tugasnya dalam rangka membantu mengentaskan kemiskinan di Provinsi Riau serta bekerja sama dengan pemerintah setempat secara intensif dan pelaksanaannya dilakukan dengan cara berkelanjutan (continue). Pengentasan kemiskinan tersebut dapat dilakukan dengan cara meningkatkan pendidikan, pelatihan, perekrutan, pendampingan dan halhal lain yang dianggap perlu.

Regulasi yang dibuat oleh pemerintah masih belum kuat adanya, mengapa demikian karena regulasi tersebut hanya mewajibkan saja, untuk bagaimana proses pelaksanaannya masih bias. Oleh sebab itu penulis menekankan perlu adanya regulasi secara spesifik yang mengatur tentang CSR ini yaitu Undang-Undang tentang CSR.

Perlu ditinjau lagi tentang penentuan klasifikasi Ring yang dilakukan oleh perusahaanperusahaan yang ada di Provinsi Riau, karena dalam implementasinya banyak Desa yang harusnya terkategorikan Ring 1 tidak mendapatkan haknya sebagaimana klasifikasi Ring 1.

\section{DAFTAR KEPUSTAKAAN}


Astuti, R. S., \& Priyadi, B. P. (2019). Analisis Peran Stakeholders Dalam Pengaturan dan Pembinaan Pedagang Kaki Lima. Jurnal Natapraja: Kajian Ilmu Administrasi Negara, 7(2), 245-258.

Azheri, Busyra. 2011. Corporate Social Responsibility, dari Voluntary menjadi Mandatory. Jakarta: PT. Raja Grafindo Persada.

Ernawan, Erni R. 2015. Tanggung Jawab Sosial Perusahaan (Corporate Social Responsibility). Jurnal Manjemen dan Bisnis ISSN 18298680 Pusat Penerbit Universitas.

Gantino, Rilla. 2016. Pengaruh Corporate Social Responsibility Terhadap Kinerja Keuangan Perusahaan Manufaktur yang Terdaftar di Bursa Efek Indonesia periode 20082014. Jurnal Dinamika Akuntansi dan Bisnis Vol. 3(2). Jakarta: Univ Esa Unggul.

Handayani, F., \& Warsono, H. 2017. Analisis Peran Stakeholders dalam Pengembangan Objek Wisata Pantai Karang Jahe di Kabupaten Rembang. Journal of Public Policy and Management Review, 6(3), 40-53.
Handjaja, Gabriela. 2013. Analisis Penerapan Corporate Social Responsibility di Perusahaan Multilevel Marketing PT. Harmoni Dinamik Indonesia. Jurnal Ilmiah Vol.2 No.2. Mahasiswa Universitas Surabaya.

Herman, H., \& Novarizal, R. 2017. Faktor-Faktor Ideal Perusahaan Dalam Pelaksanaan CSR (Corporate Social Responsibity). Sisi Lain Realita, 2(2), 39-53.

Herman, H. 2019. Pelaksanaan Corporate Social Responsibility Oleh Stakeholders Primer dan Skunder di Riau. Jurnal Ilmiah Manajemen Publik dan Kebijakan Sosial, 2(2), 264-277.

Kartasasmita, Ginanjar. 1996. Pembangunan Untuk Rakyat: Memadukan Pertumbuhan dan Pemerataan. Jakarta: PT. Cidesindo.

Kartini, Dwi. 2013. Corporate Social Responsibility: Transpormasi Konsep Sustainability Management dan Implementasi di Indonesia. Bandung: Refika Aditama.

Lawalata, G. M. 2013. PrinsipPrinsip Pembangunan Jalan Berkelanjutan. Jurnal Transportasi, 13(2). 
Mardikanto, Totok. 2014. CSR:

Corporate Social

Responsibility,

Tanggungjawab Korporasi).

Sosial

Alfabeta.

Nurbaety, Annisa. 2015. Analisis Implementasi Corporate Social Responsibility PT Bio Farma Di Desa Sukamulya Kabupaten Sukabumi. Jurnal Sosioteknologi Volume 14, Nomor 2, Agustus 2015. ITB Bandung.

Purnamasari, I. (2008). Studi partisipasi masyarakat dalam perencanaan pembangunan di Kecamatan Cibadak Kabupaten Sukabumi (Doctoral dissertation, program Pascasarjana Universitas Diponegoro).

Soemanto, Bakdi, Dkk. 2007. Sustainable Corporation: Implikasi Harmonis Perusahaan dan Masyarakat. PT. Semen Gresik (Persero) Tbk.

Suryono, A. (2010). DimensiDimensi Prima Teori Pembangunan. Universitas Brawijaya Press.

Susanto, A.B. 2007. Corporate Social Responsibility. Jakarta: The Jakarta Consulting Gruop Partner In Change.

Wahyuningrum, Yuniarti. 2015. Pengaruh Program Corporate Social Responsibility
Terhadap Penigkatan

Pemberdayaan Masyarakat (Studi pada Implementasi CSR PT. Amerta Indah Otsuka Desa Pacarkeling Kecamatan Kejayan Kabupaten Pasuruan). Jurnal Administrasi Publik (JAP), Vol.1 No.5, Malang: Universitas Brawijaya.

Wibisono, Yusuf. 2007. Membedah Konsep dan Aplikasi CSR (Corporate Social Responsibility). Jakarta: PT. Gramdedia.

$$
\begin{aligned}
& \text { Undang-Undang Nomor } 40 \text { Tahun } \\
& 2007 \quad \text { Tentang Perseroan } \\
& \text { Terbatas. }
\end{aligned}
$$

Peraturan Daerah Provinsi Riau Nomor 6 Tahun 2012 Tentang Tanggung Jawab Sosal Perusahaan dan Lingkungan Di Provinsi Riau. 